\title{
O GÊNERo Mimosa (Leguminosae-Mimosoideae) NA microrregião do Vale do Ipanema, Pernambuco ${ }^{1}$
}

\author{
Juliana Santos Silva ${ }^{2}$ \& Margareth Ferreira de Sales ${ }^{3}$
}

\section{RESUMO}

(O gênero Mimosa (Leguminosae-Mimosoideae) na microrregião do Vale do Ipanema, Pernambuco) O estudo taxonômico de Mimosa no Vale do Ipanema foi realizado através da análise morfológica de materiais de herbários e coletados em campo. Constataram-se 11 táxons distribuídos em três seções: 1) Mimosa sect. Batocaulon (M. adenocarpa, M. arenosa, M. gemmulata var. adamantina, M. lewisii, M. misera, M. ophthalmocentra e M. tenuiflora); 2) Mimosa sect. Habbasia (M. somnians); e 3) Mimosa sect. Mimosa (M. hirsutissima var. hirsutissima, M. modesta var. ursinoides e M. sensitiva var. sensitiva). Os principais caracteres morfológicos utilizados para separação das espécies foram os tipos de indumento e de inflorescências, número de pinas, foliólulos, de elementos do perianto e de estames, além do aspecto do fruto. A maior parte das espécies apresenta distribuição em vegetação de caatinga, apenas M. hirsutissima var. hirsutissima, M. gemmulata var. adamantina, M. misera e M. sensitiva var. sensitiva ocorrem em vegetação arbustiva perenifólia.

Palavras-chave: Mimosa, Mimosoideae, taxonomia, florística, Brasil.

\section{Abstract}

(Mimosa L. (Leguminosae-Mimosoideae) in the microrregion of Ipanema Valley, Pernambuco) The taxonomic study of Mimosa L. in the Ipanema Valley was based on morphologic analysis of fresh material or herbarium specimens, as well as field observations. Eleven taxa, distributed in three sections, were found: 1) Mimosa sect. Batocaulon (M. adenocarpa, M. arenosa, M. gemmulata var. adamantina, M. lewisii, M. misera, M. ophthalmocentra and M. tenuiflora ); 2) Mimosa sect. Habbasia (M. somnians); and 3) Mimosa sect. Mimosa (M. hirsutissima var. hirsutissima, M. modesta var. ursinoides and M. sensitiva var. sensitiva). The main characters used for delimitation of the species were type of indumentum, inflorescence morphology, number of pinnae, leaflets, perianth elements and stamens, as well as aspects from the fruit. Most species occur in caatinga vegetation, only M. hirsutissima var. hirsutissima, M. gemmulata var. adamantina, M. misera and M. sensitiva var. sensitiva occur in evergreen shrubby vegetation.

Key words: Mimosa, Mimosoideae, taxonomy, survey, floristics, Brazil.

\section{INTRODUÇÃO}

Mimosa L. abrange cerca de 480 espécies alocadas em cinco seções, com distribuição nos mais variados ambientes e tipos vegetacionais das regiões tropicais e subtropicais da América, apresentando como importantes centros de diversidade o Brasil, México, Paraguai, Uruguai e Argentina (Barneby 1991). Para o Brasil, estima-se cerca de 340 espécies, das quais 189 são referidas para o cerrado por Simon \& Proença (2000).

A primeira referência ao gênero Mimosa foi feita por Linnaeus (1753) no Species Plantarum, onde o autor incluiu 53 espécies, das quais 47 foram posteriormente transferidas para outros gêneros da subfamília. Tratamentos taxonômicos abrangentes sobre Mimosa são encontrados em Bentham (1841, 1875, 1876), Burkart (1948) e, mais recentemente, em Barneby (1991), que se destaca, principalmente, por ter contribuído para a sistemática atual do gênero.

No Brasil, estudos abordando a taxonomia desse gênero são escassos, destacando-se a monografia de Bentham (1876), na Flora brasiliensis, por fornecer descrições minuciosas de 199 espécies, com comentários e distribuição geográfica, constituindo uma obra relevante para os estudos do gênero. Mais recentemente, Lins (1984) revisou a série Lepidotae para o Rio Grande do Sul constatando oito espécies diferenciadas, principalmente, pelo número de folíolos, coloração das flores e pelo tipo de tricoma.

Artigo recebido em 07/2006. Aceito para publicação em 05/2007.

${ }^{1}$ Projeto financiado pela fundação O Boticário de Proteção a Natureza.

${ }^{2}$ Bolsista de Iniciação Científica - UFRPE/FACEPE. Jullybandeira@ hotmail.com

${ }^{3}$ Universidade Federal Rural de Pernambuco, Departamento de Biologia, Área de Botânica. Av. Dom Manuel Medeiros s/n, Dois Irmãos, Recife, PE. mfsales@ufrpe.br 
Para o Nordeste do Brasil merece destaque Barneby (1985), que abordou o gênero para a Bahia estabelecendo 15 novas espécies, sete variedades e nove combinações novas; Ducke (1953), que tratou de Mimosa ao estudar as leguminosas de Pernambuco e Paraíba; Lewis (1987), que referiu 65 espécies para a Bahia, e Lewis (1995), que estudou as espécies do Pico das Almas, Chapada Diamantina, Bahia. Recentemente, Lewis (2006) referiu 104 táxons de Mimosa, para o checklist das plantas do Nordeste brasileiro.

Mimosa constitui um tema relevante para estudo por apresentar muitos problemas taxonômicos a serem resolvidos. Isto ocorre em face de sua complexidade, resultante da grande diversidade morfológica, certamente, relacionada à ampla distribuição geográfica e aos diferentes tipos de hábitat em que ocorre, além do seu elevado número de táxons. Neste sentido, o presente estudo objetiva o reconhecimento das espécies de Mimosa ocorrentes na microrregião do Vale do Ipanema, como primeiro passo para o estudo do gênero em todo estado de Pernambuco.

\section{Material e Métodos}

Área de estudo - A microrregião do Vale do Ipanema, com cerca de $5.288 \mathrm{~km}^{2}$, localizase no estado de Pernambuco, aproximadamente $340 \mathrm{~km}$ do Recife, na região do Sertão do Moxotó, abrangendo os municípios de Águas Belas, Buíque, Itaíba, Pedra, Tupanatinga e Venturosa. A vegetação predominante é a caatinga, embora ocorram, também, vegetações rupestres, floresta úmida e arbustiva perenifólia.

Estudo taxonômico - Foram realizadas coletas mensais para a obtenção de material botânico e observação das populações em campo. Os exemplares coletados foram incorporados ao acervo do herbário PEUFR da Universidade Federal Rural de Pernambuco. Para padronizar as formas das estruturas vegetativas e reprodutivas utilizaram-se as terminologias propostas por Radford et al. (1974) e Bell (1991) e para o padrão de venação, Hickey (1973).

\section{Resultados e Discussão}

Mimosa L., Sp. Pl. 1: 516.1753.

Árvores, arbustos, trepadeiras ou ervas, inermes ou armadas de acúleos ou espinhos. Acúleos infra-estipulares ou dispersos irregularmente ao longo dos ramos. Folhas bipinadas, muitas vezes sensitivas ao toque, raramente ausentes ou reduzidas a filódios; estípulas inconspícuas ou, às vezes, espinescentes; pecíolo em geral sem glândulas, raramente com uma na base. Inflorescências glomeruliformes, espiciformes ou raramente racemos, axilares, solitárias ou agrupadas em racemos ou panículas axilares ou terminais. Flores pequenas, sésseis ou pediceladas, andróginas ou unissexuais, isostêmones ou diplostêmones; cálice 3-5 lobos, gamossépalo, membranáceo, campanulado, tubular ou papiforme; corola 3-5 lobos, gamopétala, campanulada, creme, rósea ou púrpura nos lobos; estames livres ou brevemente unidos na base, exsertos, brancos, creme, róseos ou lilases; anteras dorsifixas, não glandulares; ovário, em geral, séssil, com dois ou mais óvulos; estilete filiforme, estigma apical, inconspícuo. Fruto craspédio, séssil ou estipitado, linear, elíptico ou oblongo, membranáceo ou coriáceo, armado ou inerme; sementes plano-compressas, elipsóides, oblongóides ou ovóides.

\section{Chave para identificação das seções e espécies de Mimosa ocorrentes na microrregião do Vale do Ipanema}

1. Flores diplostêmones.

2. Corola com lobos estriados 2. sect. Habbasia; 2.1. M. somnians

2'. Corola com lobos não estriados 1. sect. Batocaulon

3. Inflorescências glomeruliformes.

4. Flores trímeras; corola rósea 1.5. M. misera

4'. Flores tetrâmeras; corola creme. 
5. Estípulas espinescentes; foliólulos com ápice arredondado, margem não ciliada; inflorescências agrupadas em panícula terminal; filetes brancos ....... 1.4. M. lewisii

5'. Estípulas não espinescentes; foliólulos com ápice mucronado, margem ciliada; inflorescências solitárias, axilares; filetes lilases 1.1. M. adenocarpa

3'. Inflorescências espiciformes.

6. Ramos aculeados; nervação hifódroma ou eucampdódroma.

7. Foliólulos com glândulas translúcidas; nervação hifodróma; cálice 4-costelas ... 1.7. M. tenuiflora

7’. Foliólulos sem glândulas translúcidas; nervação eucampdódroma; cálice tubular 1.6. M. ophthalmocentra

6'. Ramos inermes; nervação cladódroma ou acródroma.

8. Folha com 4-12 pinas; nervação acródroma; corola glabra; filetes brancos; fruto linear, glabro

1.2. M. arenosa

8'. Folha com 16-22 pinas; nervação cladódroma; corola com glândulas entremeadas aos tricomas simples; filetes róseos; fruto elíptico, revestido por glândulas acobreadas adensadas 1.3. M. gemmulata var. adamantina

1'. Flores isostêmones 3. sect. Mimosa

9. Planta armada; ramos cilíndricos; nervação acródoma ou cladódroma.

10. Acúleos distribuídos densamente nos ramos, pecíolos e pedúnculos; pecíolo anguloso; foliólulos membranáceos, oval-lanceolados, base truncada; nervação broquidódroma; ovário glabro 3.3. M. sensitiva var. sensitiva

10'. Acúleos infrapeciolares; pecíolo caniculado; foliólulos cartáceos, oblongos, base arredondada; nervação acródroma; ovário pubescente ..... 3.1. M. hirsutissima var. hirsutissima

9'. Planta inerme; ramos sulcados; nervação actinódroma .... 3.2. M. modesta var. ursinoides

1. Mimosa sect. Batocaulon DC., Prodr. 2: 429. 1825

Apresenta cerca de 190 espécies, com distribuição predominantemente americana, sendo considerada uma das mais polimórficas do gênero. $\mathrm{Na}$ área de estudo ocorrem sete espécies.

1.1. Mimosa adenocarpa Benth., J. Bot. (Hooker) 4: 399. 1842.

Fig. 1 a-e

Arbusto 2-2,5 m alt. Tricomas glandulares e simples, distribuídos nos ramos, estípulas, pecíolo, foliólulos, raque, pedúnculos, brácteas e no ápice da corola. Ramos cilíndricos, aculeados; acúleos retos; estípulas 6-9 mm compr., estreitamente triangulares, não espinescentes. Folhas 14-22 pinas; pecíolo 0,8-2,3 cm compr., caniculado, aculeado; raque 3-5 mm compr., caniculada, aculeada; pinas 1,5-4 cm compr., 32-56 folioluladas; foliólulos cartáceos, oblongos, base oblíqua, ápice mucronado, margem ciliada, face adaxial glabra, abaxial pubescente; nervação hifódroma. Inflorescências glomeruliformes, solitárias, axilares; pedúnculo 2,5-3 cm compr.; brácteas 3-3,2 mm compr., triangulares, ciliadas. Botões 2-2,1 mm compr. Flores diplostêmones, tetrâmeras, sésseis; cálice $0,7-0,8$ mm compr., tubuloso, 4-denteado, discretamente ciliado; corola 4-4,3×0,9-1 mm, campanulada, creme, tricomas glandulares adensados no ápice, lobos 4, lanceolados; estames 8, livres; filete 1,2-1,3 mm compr., lilás; antera oblongo-ovóide; ovário 23,3 mm compr., séssil, seríceo; óvulos 6-11; estilete 8-9 mm compr. Fruto não observado. Material examinado: BRASIL. PERNAMBUCO: Buíque, serra do Catimbau, 10.VII.2005, fl., J. S. Silva et al. 124 (PEUFR); A. S. A. Alves et al. 54 (PEUFR). Material adicional: BRASIL. BAHIA: Rio de Contas, 4.IV.1966, fl., J. S. Sobrinho 245 (HST).

Mimosa adenocarpa é facilmente reconhecida pelos tricomas glandulares adensados no ápice dos lobos da corola, ovário (ca. $3 \mathrm{~mm}$ ) seríceo e estípulas (6-9 mm) maiores que nas demais espécies $(0,2-4,8 \mathrm{~mm})$. É registrada para os estados da Bahia, Goiás, Mato Grosso do Sul e Minas Gerais (Barneby 
1991), e referida pela primeira vez para Pernambuco neste trabalho. Até agora foi apenas localizada em Buíque, em vegetação de caatinga, em solos arenosos. Floresce em julho.

1.2. Mimosa arenosa (Willd.) Poir., Encycl. Suppl.1: 66. 1810.

Fig. $1 \mathrm{f}-\mathrm{i}$

Arbusto 2,5-3,5 m alt. Ramos cilíndricos, inermes e aculeados, tomentosos; acúleos incurvados; estípulas 2-3,2 mm compr., estreitamente triangulares, velutino-pubescentes. Folha 4-12 pinas; pecíolo 0,9-1,7 cm compr., sulcado, tomentoso; raque $0,7-1 \mathrm{~cm}$ compr., discretamente sulcado, puberulento; pinas 13,5 cm compr., 12-40 folioluladas; foliólulos membranáceos, oblongos, ápice mucronadomucronulado, base oblíqua, margem inteira, puberulentos a glabros; nervação acródroma. Inflorescências espiciformes, solitárias, axilares; pedúnculo 0,5-1 cm compr., pubescente; brácteas 1-1,2 mm compr., lanceoladas, ciliadas. Botões 0,9-1,4 mm compr. Flores diplostêmones, tetrâmeras, curtamente pediceladas, glabras; cálice 0,5-0,8 mm compr., tubular, 4-denteado, discretamente ciliado; corola 2-2,3 $\times 0,9-1 \mathrm{~mm}$, campanulada, creme, glabra, lobos 4, lanceolados; estames 8, livres; filete 4,5-5 mm compr., branco; antera oblongo-ovóide; ovário $1 \mathrm{~mm}$ compr., séssil, glabro; óvulos 4-8; estilete 5-6,4 mm compr. Craspédio 3,5-4,4 × 0,4-0,5 cm, estipitado, membranáceo, linear, plano-compresso, base atenuada, ápice mucronado, glabro, marromescuro; replo reto, glabro. Sementes 5-8, ovóides, plano-compressas, marrons.

Material examinado: BRASIL. PERNAMBUCO: Águas Belas, barragem Grande de Lameirão, 9.IX.2003, fl., E. B. Ferraz \& J. Roberto 2 (IPA); próximo à fazenda Nova, 29.XI.1989, fl., D. A. Lima 69-5610 (IPA); Buíque, estrada para Catimbau, 9.VII.1995, fl., K. Andrande \& L. Figueiredo 115 (PEUFR); Pedra, reserva da Igreja, fl., 2.VII.2006, J. S. Silva et al. 260 (PEUFR); Venturosa, estrada para Alagoinha, 2.VII.2006, fl., J. S. Silva et al. 268 (PEUFR).

Mimosa arenosa pode ser reconhecida pelos ramos tomentosos, foliólulos membranáceos, flores curtamente pediceladas e frutos glabros. Apresenta afinidades com M. ophthalmocentra, com a qual compartilha o hábito arbustivo, a presença de acúleos, as inflorescências espiciformes, o mesmo número de estames (8), os filetes brancos e o fruto plano-compresso. No entanto, diferenciam-se principalmente por que em M. ophthalmocentra a corola é 4angulada, o craspédio é séssil e puberulento e os foliólulos são eucamptódromos e cartáceos, enquanto em $M$. arenosa a corola é campanulada, o craspédio é estipitado e glabro e os foliólulos são acródomos e membranáceos. A espécie é referida para América Central (México) e América do Sul (Brasil, Colômbia e Venezuela) (Barneby 1991). No Brasil ocorre nos estados do Ceará, Minas Gerais, Pernambuco (Sales et al. 1998), Rio de Janeiro e Rio Grande do Norte (Barneby 1991). Na área de estudo foi coletada na caatinga, em solos arenosos. Floresce de junho a novembro e frutifica em novembro. É conhecida popularmente como jurema-branca.

\subsection{Mimosa gemmulata var. adamantina} Barneby, Brittonia 37: 132. 1985 . Fig. 1 j-1 Arbusto 1-2,5 m alt. Glândulas acobreadas e tricomas simples, distribuídos nos ramos, raque, pecíolo, foliólulos, pedúnculo e flores. Ramos canaliculados, inermes; estípulas 1,6$1,8 \mathrm{~mm}$ compr., triangulares, puberulentas. Folhas 16-22 pinas; pecíolo 0,7-10 cm compr., canaliculado, puberulento; raque $0,3-0,7 \mathrm{~mm}$ compr., puberulenta; pinas $2-8 \mathrm{~cm}$ compr., 30 86 folioluladas, foliólulos cartáceos, oblongos, base oblíqua, ápice acuminado, margem ciliada, face adaxial puberulento-pubescente, abaxial densamente revestida por glândulas acobreadas; nervação cladódroma. Inflorescências espiciformes, solitárias, axilares; pedúnculo 1,5-2 cm compr.; brácteas não observadas. Botões 1,5-1,7 mm compr. Flores diplostêmones, tetrâmeras, sésseis; cálice 0,6-0,9 mm compr., tubular, 4-denteado, externamente com glândulas e tricomas simples e internamente glabro; corola $2-2,1 \times 0,8-0,9 \mathrm{~mm}$, campanulada, creme, glândulas entremeadas aos tricomas simples no ápice, lobos 4, ovais; estames 7-9, livres; filete 6,8-8 mm compr., róseo; antera oblonga; ovário séssil, ca. $1 \mathrm{~mm}$ compr., densamente viloso; óvulos 8; estilete $7 \mathrm{~mm}$ compr. Craspédio 1,3$3 \times 0,4-0,5 \mathrm{~cm}$, estipitado, cartáceo, elíptico, 


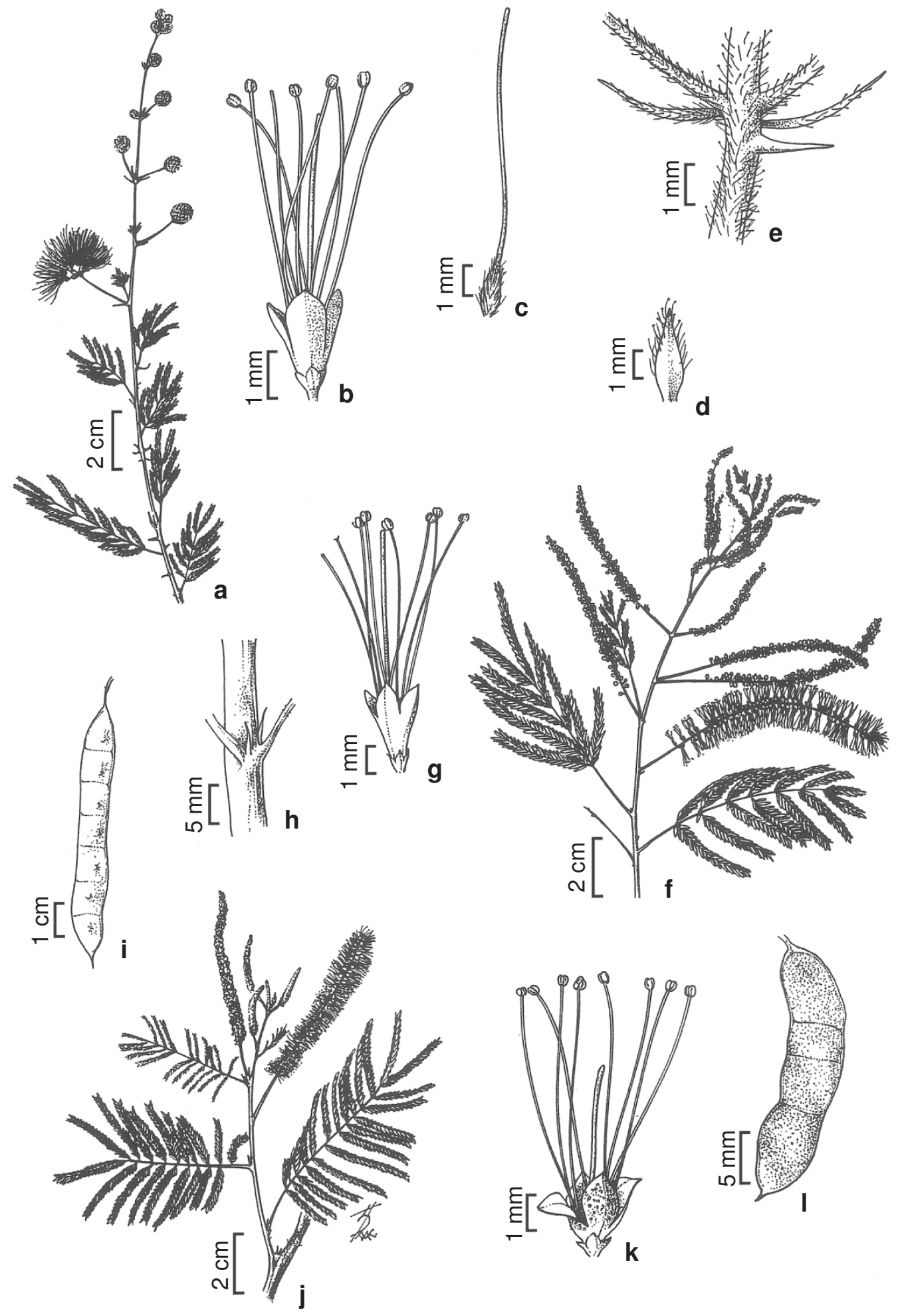

Figura 1 - a-e. Mimosa adenocarpa - a. aspecto geral do ramo; b. flor; c. gineceu; d. bráctea; e. detalhe das estípulas e acúleo (Silva 124). f-i. M. arenosa - f. aspecto geral do ramo; g. flor; h. detalhe das estípulas; i. fruto (Andrade 115). j-1. M. gemmulata var. adamantina - j. aspecto geral do ramo; k. flor; 1. fruto (Gomes 427). 
plano-compresso, base aguda, ápice cuspidado, glândulas acobreadas adensadas, marrom-escuro; replo discretamente ondulado, densamente revestido por glândulas acobreadas. Sementes 7-8, ovóides, plano-compressas, marrons.

Material examinado: BRASIL. PERNAMBUCO: Buíque, serra de Catimbau, 12.I.1996, fl. e fr., $K$. Andrande etal. 299(PEUFR); 8.V.1995, fl.,A.P.S. Gomes et al. 304 (PEUFR); caminho para o Breu, 12.IV.1996, fl., A. P. S. Gomes \& M. J. N. Rodal 330 (PEUFR).

Distingue-se das outras espécies de Mimosa ocorrentes na área de estudo, principalmente, por apresentar glândulas acobreadas nas partes vegetativas e florais, pelo maior $(0,7-10 \mathrm{~cm})$ tamanho do pecíolo e número de pinas (14 a 20), pelo número de estames variando de sete a nove e pelo ovário viloso. Barneby (1991), baseando-se, especialmente, no número de pinas e foliólulos, propôs para esta espécie quatro variedades: $M$. gemmulata var. gemmulata, M. gemmulata var. adamantina, M. gemmulata var. segrex e M. gemmulata var. cristalina. No Vale do Ipanema todos os indivíduos analisados pertencem a variedade adamantina. É exclusiva do nordeste brasileiro, em vegetação de caatinga, cerrado e carrasco, nos estados da Bahia (Barneby 1985; 1991; Lewis 1987) e Pernambuco (Sales et al. 1998). No vale ocorre em vegetação arbustiva perenifólia, em solos arenosos. Foi coletada com flores em janeiro, abril, maio e agosto e com fruto em janeiro.

\subsection{Mimosa lewisii Barneby, Brittonia 37:} 136. 1985.

Fig. 2 a-f

Arbusto 1,2-2,5 m alt. Tricomas glandulares e simples, distribuídos nos ramos, estípulas, pecíolo, margem dos foliólulos, raque, pedúnculos, brácteas e frutos. Ramos cilíndricos, aculeados, puberulento-pubescentes; acúleos discretamente incurvados; estípulas 2-2,5 mm compr., espinescentes. Folhas 14-20 pinas; pecíolo 1,3-2 mm compr., subcilíndrico, glabro na porção adaxial e puberulento na abaxial; raque 0,6-1 cm compr., subcilíndrica, puberulenta; pinas 2,5-4 cm compr., 42-68 folioluladas; foliólulos cartáceos, oblongos, base oblíqua, ápice arredondado, margem não ciliada, glabro; nervação hifódroma. Inflorescências glomeruliformes agrupadas em panículas terminais, ultrapassando a folhagem; pedúnculo 3,5-5,5 cm compr.; brácteas 2-2,1 mm compr., espinescentes. Botões 1,5-3,3 mm compr. Flores diplostêmones, tetrâmeras, sésseis, glabras; cálice 2-2,2 mm compr., tubular, discretamente 4-denteado; corola 4-5,8 × 1,4$1,5 \mathrm{~mm}$, campanulada, creme, glabra, lobos 4 , oblongo-lanceolados; estames 8, livres; filete 3,5-5 mm compr., branco; antera oblongaovóide; ovário 1,7-1,8 mm compr., séssil, glabro; óvulos 10-12; estilete $3 \mathrm{~mm}$ compr. Craspédio 9,4-12,7 ×0,7-0,8 cm, estipitado, cartáceo, linear-oblongo, superfície ondulada, base aguda, ápice mucronado, puberulento com tricomas glandulares esparsos, marrom-escuro; replo discretamente ondulado, glabro. Sementes 10-12, elipsóides, amarronzadas.

Material examinado: BRASIL. PERNAMBUCO: Buíque, estrada para Catimbau, 19.V.1994, fr., A. M. Miranda et al. 1723 (PEUFR); 19.XI.1995, fl. e fr., $L$. Figueiredo et al. 252 (PEUFR); 26.VII.2005, fl. e fr., J. S. Silva et al. 57(PEUFR); 18.VI.1994, fl., A. M. Miranda et al. 1723 (HST); serra do Catimbau, 11.IX.1994, fl. e fr., M. J. N. Rodal 437 (PEUFR); 18.IX.1994, fl., M. J. N. Rodal 436 (PEUFR); 10.I.1996, fl., K. Andrade et al 269 (PEUFR); fazenda Cajueiro, 10.IV.1955, fl.e fr., D. A. Lima 55-2024 (IPA); Tupanatinga, 30.VII.2006, fl., J. S. Silva et al. 226 (PEUFR).

Mimosa lewisii é facilmente identificada pelas inflorescências glomerulifomes agrupadas em panículas terminais, estípulas espinescentes e tricomas glandulares adensados nos pedúnculos florais, além do tamanho do craspédio $(12 \mathrm{~cm})$. No campo é de fácil reconhecimento devido à elevação das inflorescências, cerca de $30 \mathrm{~cm}$, em relação às folhas. Tem distribuição restrita ao Brasil, sendo registrada para Bahia (Barneby 1985; Lewis 1987) e Pernambuco (Sales et al. 1998). No Vale do Ipanema cresce em vegetação de caatinga em solos arenosos. Floresce de janeiro a novembro e frutifica de abril a novembro.

1.5. Mimosa misera Benth., J. Bot. (Hooker) 4: 411.1842.

Fig. 2 g-j

Subarbusto ca. $70 \mathrm{~cm}$ alt., escandente. Tricomas glandulares nas margens e face abaxial dos foliólulos, na raque e nos eixos e pedúnculos das inflorescências. Ramos cilíndricos, estriados, 


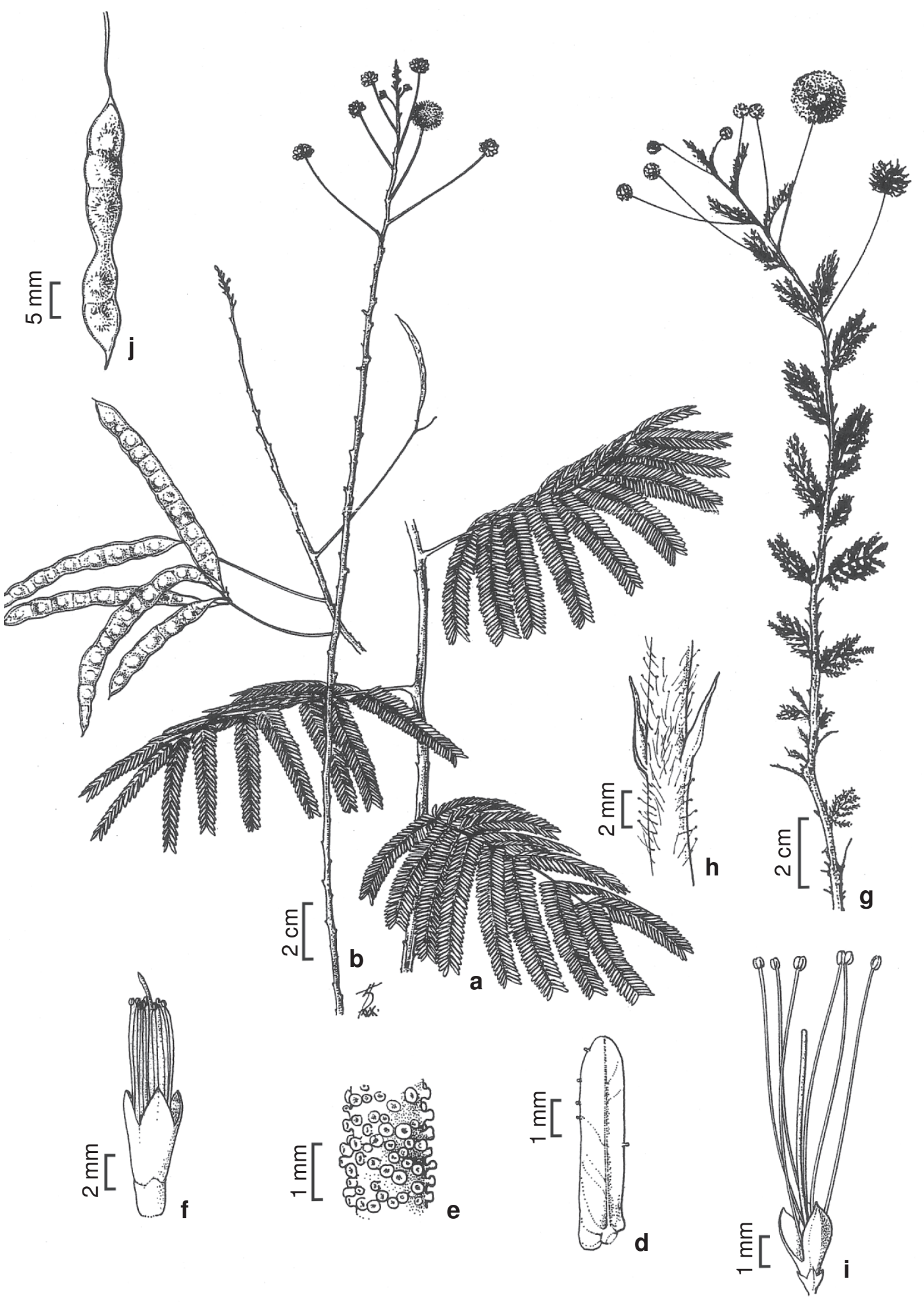

Figura 2 - a-f. Mimosa lewisii - a. aspecto geral do ramo; b. eixo floral; c. detalhe dos frutos; d. foliólulo, face abaxial; e. detalhe dos tricomas glandulares no pedúnculo; f. flor (Silva 57). g-j. M. misera - g. aspecto geral do ramo; h. detalhe das estípulas; i. flor; j. fruto (Silva 73). 
inermes a aculeados, viloso-pubescentes; acúleos retos; estípulas 2-3 mm compr., triangulares, estriadas, densamente ciliadas. Folhas 4-6 pinas; pecíolo 2-5 mm compr., cilíndrico, viloso na porção adaxial e glabro na abaxial; raque 2,4-2,5 mm compr., cilíndrica, vilosa na porção adaxial e glabra na abaxial; pinas 0,5-1,5 cm compr., 12-20 folioluladas; foliólulos cartáceos, oblongos, base oblíqua, ápice arredondado, margem esparsamente ciliada, face adaxial glabra, abaxial pubescente; nervação hifódroma. Inflorescências glomeruliformes, solitárias, axilares; pedúnculo 2-7,5 cm compr.; brácteas não observadas. Botões 1,5-1,6 mm compr. Flores diplostêmones, trímeras, sésseis, glabras; cálice 0,4-0,5 mm compr., tubular, 3-denteado; corola 2,7-2,8 $\times$ 0,8-1 mm, campanulada, rósea, lobos 3 , ovais; estames 6, livres; filete 2,8-2,9 mm compr., róseos; antera oblongo-ovóide; ovário 0,9-1 mm compr., séssil, glabro; óvulos 4; estilete 1,72,7 mm compr. Craspédio 1,8-3 ×0,3 cm, estipitado, cartáceo, elíptico, superfície ondulada, base atenuada, ápice cuspidado, puberulentoescabroso, pardacento; replo ondulado, puberulento. Sementes 3-7, oblongóides, marrons. Material examinado: BRASIL. PERNAMBUCO: Buíque, estrada Buíque - Catimbau, 4.V.1995, fl., $M$. J. N. Rodal \& K. Andrade 530 (PEUFR); 26.VII.2005, fl., J. S. Silva et al. 73 (PEUFR); serra de Catimbau, 19.X.1994, fr., M. F. Sales 433 (PEUFR).

Distingue-se claramente das demais espécies por apresentar flores trímeras, diplostêmones, e pelas pinas de tamanho bastante reduzido $(0,5-1,5 \mathrm{~cm})$ e com o menor número de foliólulos (12-20), além da face adaxial vilosa. Apresenta maiores afinidades com M. guaranitica Chodat \& Hassl., por ambas apresentarem hábito subarbustivo, inflorescências glomeruliformes e flores trímeras diplostêmones, embora difiram, principalmente, quanto a consistência dos foliólulos, membranáceos em M. guaranitica e cartáceos em M. misera. Tem distribuição exclusiva no Brasil, sendo referida para Bahia, Ceará, Pernambuco e Piauí (Barneby 1991). Na área de estudo cresce em vegetação arbustiva perenifólia, em solos arenosos. Floresce em maio e julho e frutifica em outubro.
1.6. Mimosa ophthalmocentra Mart. ex Benth., Trans. Linn. Soc. London 30: 415. 1875.

Fig. 3 a-d

Arbusto ca. $5 \mathrm{~m}$ alt. Ramos cilíndricos, sulcados na porção jovem, aculeados, puberulentos; acúleos retos; estípulas 4,3-4,8 mm compr., triangulares, estriadas, tomentosas. Folhas 4-8 pinas; pecíolo 3-4 mm compr., sulcado, puberulento; raque 4-5 mm compr., angulosa, puberulentotomentosa; pinas 1,5-2,5 cm compr., 22-36 folioluladas; foliólulos cartáceos, oblongos, ápice discretamente agudo, base oblíqua, margem discretamente ciliada, glabros, sem glândulas translúcidas; nervação eucamptódroma. Inflorescências espiciformes, solitárias, axilares; pedúnculo 0,5-1 cm compr., puberulento; brácteas 1,5-1,8 mm compr., lanceoladas, puberulento-tomentosas. Botões 1,5-1,8 mm compr. Flores diplostêmones, tetrâmeras, sésseis; cálice 0,9-1 mm compr., tubular, discretamente 4-denteado, ciliado; corola 2-2,2 $\times 0,8-0,9 \mathrm{~mm}$, campanulada, creme, glabra, 4-angulada, lobos 4, oblongo-lanceolados; estames 8, livres; filete 3,5-6 mm compr., branco; antera oblonga; ovário 0,8-1 mm compr., séssil, glabro; óvulos 8; estilete 4-4,2 mm compr. Craspédio 2,4$5,3 \times 0,5-0,7 \mathrm{~cm}$, séssil, cartáceo, estreitamente oblongo, plano-compresso, base redonda, ápice redondo, puberulento, marrom-vináceo; replo reto, glabrescente. Sementes 5-8, ovóides, plano-compressas, marrons.

Material examinado: BRASIL. PERNAMBUCO: Buíque, fazenda Laranjeiras, 7.XII.1996, fl., L. Figueiredo et al. 276 (PEUFR).

Material adicional: BRASIL. PERNAMBUCO: Brejo da Madre de Deus, Fazenda Nova, fazenda Araras, 16. IX.1998, fl. e fr., L. Figueiredo \& K. Andrade 483 (PEUFR); Petrolina, 25.X.1980, fl., D. A. Lima 80-891 (IPA); Serra Talhada, estrada Carqueja, 16.VII.1980, fl., D. A. Lima et al. 25272 (IPA).

Mimosa ophthalmocentra é facilmente identificada por ser a única espécie que tem a corola 4-angulada e o craspédio planocompresso séssil. É frequentemente confundida com M. arenosa e M. tenuiflora. Com a última compartilha o hábito arbustivo, presença de acúleos e inflorescências espiciformes. Entretanto, M. tenuiflora se diferencia por 


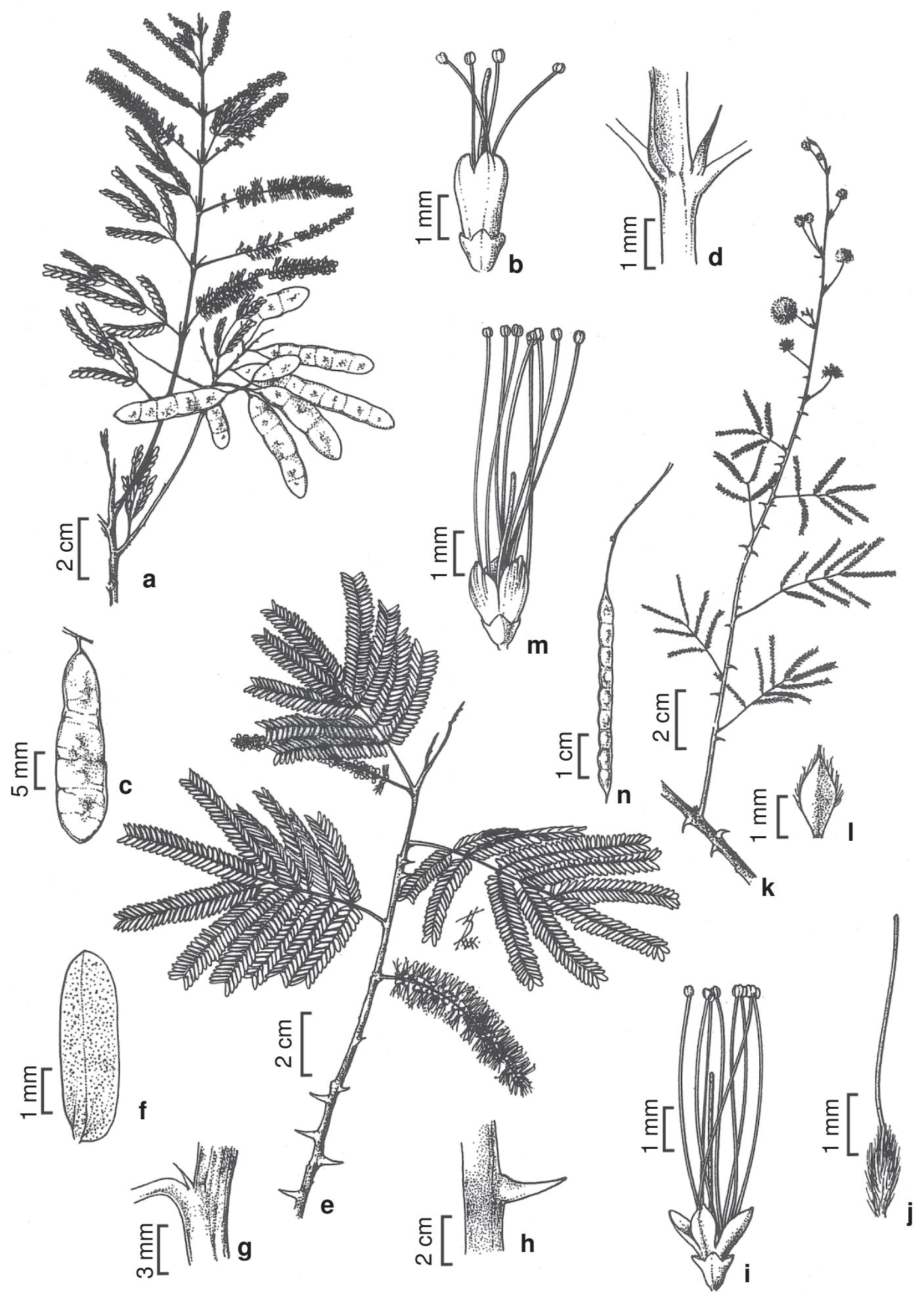

Figura 3 - a-d. Mimosa ophthalmocentra - a. aspecto geral do ramo; b. flor; c. fruto; d. detalhe das estípulas (Figueiredo 276). e-j. M. tenuiflora - e. aspecto geral do ramo; f. foliólulo evidenciando glândulas translúcidas; g. detalhe das estípula; h. detalhe de um acúleo; i. flor; j. gineceu (Silva 117). k-n. M. somnians - k. aspecto geral do ramo; 1. bráctea; m. flor; n. fruto (Rodal 422). 
apresentar cálice com 4-costelas proeminentes e incurvadas, cerca de 10-12 pinas (4-6 em $M$. ophthalmocentra) e, especialmente, glândulas translúcidas nos foliólulos. É exclusiva do Brasil ocorrendo amplamente no Distrito Federal, Bahia, Rio Grande do Norte (Barneby 1991) e Pernambuco (Sales et al. 1998), em áreas de caatinga e cerrado. No Vale do Ipanema foi coletada em caatinga, crescendo em solos arenosos. Floresce em dezembro. É conhecida popularmente como jurema-de-embira.

1.7. Mimosa tenuiflora (Willd.) Poir., Encycl. Suppl.1: 82.1810.

Fig. 3 e-j

Arbusto ou árvore 2-5 m alt. Tricomas simples e glandulares distribuídos nos ramos, estípulas, pecíolo, raque, eixo floral e fruto. Ramos cilíndricos, aculeados; acúleos retos; estípulas 0,9-1 mm compr., triangulares, ciliadas. Folhas 10-12 pinas; pecíolo 0,9-1,3 cm compr., discretamente sulcado; raque 3-6 mm compr., sulcado; pinas 2,5-5,3 cm compr., 3062 folioluladas; foliólulos cartáceos, oblongos, ápice redondo, base oblíqua, margem curtamente ciliada, com glândulas translúcidas perceptíveis na face abaxial, glabros a puberulentos; nervação hifódroma. Inflorescências espiciformes, solitárias, axilares; pedúnculo 0,4-0,5 cm compr., puberulento; brácteas 0,9-1 mm compr., lanceoladas, incurvadas no ápice, ciliadas. Botões 1-1,4 mm compr. Flores diplostêmones, tetrâmeras, sésseis; cálice 1-1,2 mm compr., tubular, 4-costelas proeminentes, incurvadas, puberulento, mais adensados no ápice; corola 2-2,3 × 0,8-0,9 mm, campanulada, creme, glabra, lobos 4, ovais; estames 8, livres; filete 3-4 mm compr., creme; antera oblonga; ovário ca. $1 \mathrm{~mm}$ compr., séssil, puberulento; óvulos 4-8; estilete 4,7-7 mm compr. Craspédio 3,3$4 \times 1 \mathrm{~cm}$, estipitado, cartáceo, oblongo, superfície ondulada, base atenuada, ápice mucronado, amarelado; replo ligeiramente ondulado, puberulento, tricomas glandulares esparsos. Sementes 4-8, ovóides, marrons.

Material examinado: BRASIL. PERNAMBUCO: Águas Belas, 29.VII.2006, fl., J. S. Silva et al. 208 (PEUFR);Venturosa, Parque da Pedra Furada, 4.VIII.1998, fl., K. C. Costa et al. 117 (PEUFR); sítio
Carrapateira, 17.XII.1997, fr., E. B. Ferraz \& C. Ferreira 182 (IPA); estrada para Alagoinha, 2.VII.2006, fl., J. S. Silva et al. 269 (PEUFR).

Mimosa tenuiflora é facilmente reconhecida pela presença de glândulas translúcidas perceptíveis na face abaxial dos foliólulos, ovário puberulento e, principalmente, pelo cálice tubular com 4-costelas proeminentes e incurvadas. De acordo com Barneby (1991) está distribuída no México, Brasil, Colômbia e Venezuela. No Brasil, ocorre na Bahia, Ceará, Minas Gerais, Rio Grande do Norte e São Paulo. No Vale do Ipanema, encontra-se em diferentes feições da vegetação de caatinga. Floresce em agosto e frutifica em dezembro. Popularmente é conhecida por jurema-preta.

2. Mimosa sect. Habbasia DC., Prodr. 2: 428. 1825.

Compreende 78 espécies distribuídas na América do Sul e do Norte. Apenas uma espécie ocorre no Vale do Ipanema.

2.1. Mimosa somnians Humb. \& Bonpl. ex Willd., Sp. Pl. 4(1): 1036. $1806 . \quad$ Fig. 3 k-n

Arbusto 2-2,5 m alt. Ramos cilíndricos, aculeados, glabrescentes; acúleos incurvados; estípulas 0,2-0,3 mm compr., triangulares, ciliadas. Folhas 4-6 pinas; pecíolo 1,8-2 mm compr., cilíndrico, glabro; raque $0,5-0,7 \mathrm{~mm}$ compr., caniliculada, glabra; pinas 1-1,7 cm compr., 3042 folioluladas; foliólulos cartáceos, oblongos, base oblíqua, ápice arredondado, margem curtamente ciliada, glabros; nervação eucamptódroma. Inflorescências glomeruliformes, axilares; pedúnculos 1-3 cm compr., glabro; brácteas 1,2-1,3 mm compr., triangulares. Botões 1,2-1,8 mm compr. Flores diplostêmones, tetrâmeras, sésseis, glabras; cálice $0,8-1 \mathrm{~mm}$ compr., tubular, lobos discretamente ciliado; corola 2,5-3 $\times 1 \mathrm{~mm}$, campanulada, creme com a porção apical rósea, lobos 4 , obovais, estriados; estames 8, livres; filete $6-7,8 \mathrm{~mm}$ compr., discretamente dilatado no ápice, róseo; antera oblongo-ovóide; ovário 0,9-1 mm compr., séssil, glabro; óvulos 9; estilete 2,52,7 mm compr. Craspédio 5-5,5 ×0,3-0,4 cm, estipitado, cartáceo, linear, superfície ondulada, 
base aguda, ápice cuspidado, marrom-claro; replo constrito entre os segmentos seminais, escabroso. Sementes 6-9, ovóides, marrons. Material examinado: BRASIL. PERNAMBUCO: Buíque, fazenda Esmeralda, 18.X.1994, fl. e fr., M. J. N. Rodal 422 (PEUFR).

Material adicional: BRASIL. PERNAMBUCO: Recife, engenho Uchôa, 8.IX.1996, fl., C. Eugenio 17 (IPA).

Difere dos demais táxons estudados pelos ramos glabrescentes, estípulas reduzidas $(0,2-$ $0,3 \mathrm{~mm}$ ) e, principalmente, pela corola com lobos obovais estriados no ápice e replo escabroso, constrito entre os segmentos seminais. Mimosa somnians é referida por Barneby (1991) para a Bolívia e Brasil (AP, MS e SP). Na área de estudo ocorre no complexo caatinga-campo, em área degradada, em solos arenosos. Coletado com flores e fruto em outubro.

3. Mimosa sect. Mimosa L., Sp. P1. 1: 516.1753 .

Seção predominantemente americana englobando cerca de 160 espécies das quais três ocorrem na área estudada.

3.1. Mimosa hirsutissima Mart. var. hirsutissima, Flora 21 (2, Beibl. 4-5): 55. 1838.

Fig. 4 a-c

Subarbusto $60-80 \mathrm{~cm}$ alt., decumbente. Ramos cilíndricos, aculeados, hirsutos; acúleos infrapeciolares, retos; estípulas $0,6-0,7 \mathrm{~mm}$ compr., lanceoladas, estrigoso-hirsutas. Folhas 2 pinas; pecíolo ca. $1 \mathrm{~cm}$ compr., caniculado, escabroso; pinas 2,5-3 cm compr., 10-24 folioluladas; foliólulos cartáceos, oblongos, base arredondada, ápice acuminado, margem ciliada, seríceos; nervação acródroma. Inflorescências glomeruliformes, solitárias, axilares; pedúnculo 4-6,5 cm compr., hirsuto; brácteas 1,4-1,6 mm compr., linear-oblanceoladas, ciliadas no ápice. Botões 1,1-1,9 mm compr. Flores isostêmones, tetrâmeras, sésseis; cálice 1,3-1,5 mm compr., papiforme, glabro; corola 3-3,1×0,3-0,4 mm, campanulada, creme, externamente puberulenta na região apical e internamente glabra, lobos 4 , lanceolados, discretamente incurvados no ápice; estames 4, livres; filete 4,8-7 mm compr., róseo; antera obovóide; ovário 1-1,5 mm compr., séssil, pubescente, tricomas distribuídos lateralmente; óvulos 4-5; estilete 6,5-7,9 mm compr. Fruto não observado.

Material examinado: BRASIL. PERNAMBUCO: Buíque, estrada para Catimbau, 15.I.1995, fl., $K$. Andrade et al. 82 (PEUFR); 10.VII.1997, fl., N. F. Dornelas et al. 29 (HST); 26.VII.2005, fl., J. S. Silva et al. 72 (PEUFR); fazenda Mina Grande, 23.III.2005, fl., C. Cosmo 1 (IPA).

Mimosa hirsutissima var. hirsutissima pode ser identificada pelo seguinte conjunto de caracteres: ramos hirsutos, acúleos infrapeciolares, foliólulos seríceos e ovário pubescente cujos tricomas estão distribuídos lateralmente. O número de foliólulos e o tipo de indumento foram características utilizadas por Barneby (1991) para reconhecer, para esta espécie, três variedades: $M$. hirsutissima var. barbigera, M. hirsutissima var. grossa e $M$. hirsutissima var. hirsutissima. Todos os indivíduos no Vale do Ipanema pertencem a M. hirsutissima var. hirsutissima. Está amplamente distribuída na América do Sul, sendo encontrada na Argentina, Brasil, Colômbia, Paraguai e Venezuela (Barneby 1991). No Brasil é referida para as Regiões Nordeste (BA, CE, $\mathrm{PB}, \mathrm{PE}$ ), Centro-Oeste (GO, MS), Sudeste (ES, MG, SP) e Sul (PR) (Barneby 1991). Na área de estudo, cresce em vegetação arbustiva perenifólia. Floresce em março, junho e julho.

\subsection{Mimosa modesta var. ursinoides (Harms) Barneby, Brittonia 37: 147. 1985.}

Fig. 4 d-h

Subarbusto 80-90 cm alt., decumbente. Ramos sulcados, inermes, puberulento-estrigosos; estípulas ca. $4 \mathrm{~mm}$ compr., triangulares, estriadas, tomentosas. Folhas 2 pinas; pecíolo 2,2-2,4 cm compr., sulcado, puberulento-estrigoso; pinas 2-2,5 cm compr., 4-10 folioluladas, foliólulos cartáceos, obovais, base arredondada, ápice mucronado, margem ciliada, face adaxial glabra, abaxial puberulento-estrigosa; nervação actinódroma. Inflorescências glomeruliformes, solitárias, axilares; pedúnculo $3-5 \mathrm{~cm}$ compr., pubescente; bráctea $0,7-0,8 \mathrm{~mm}$ compr., 


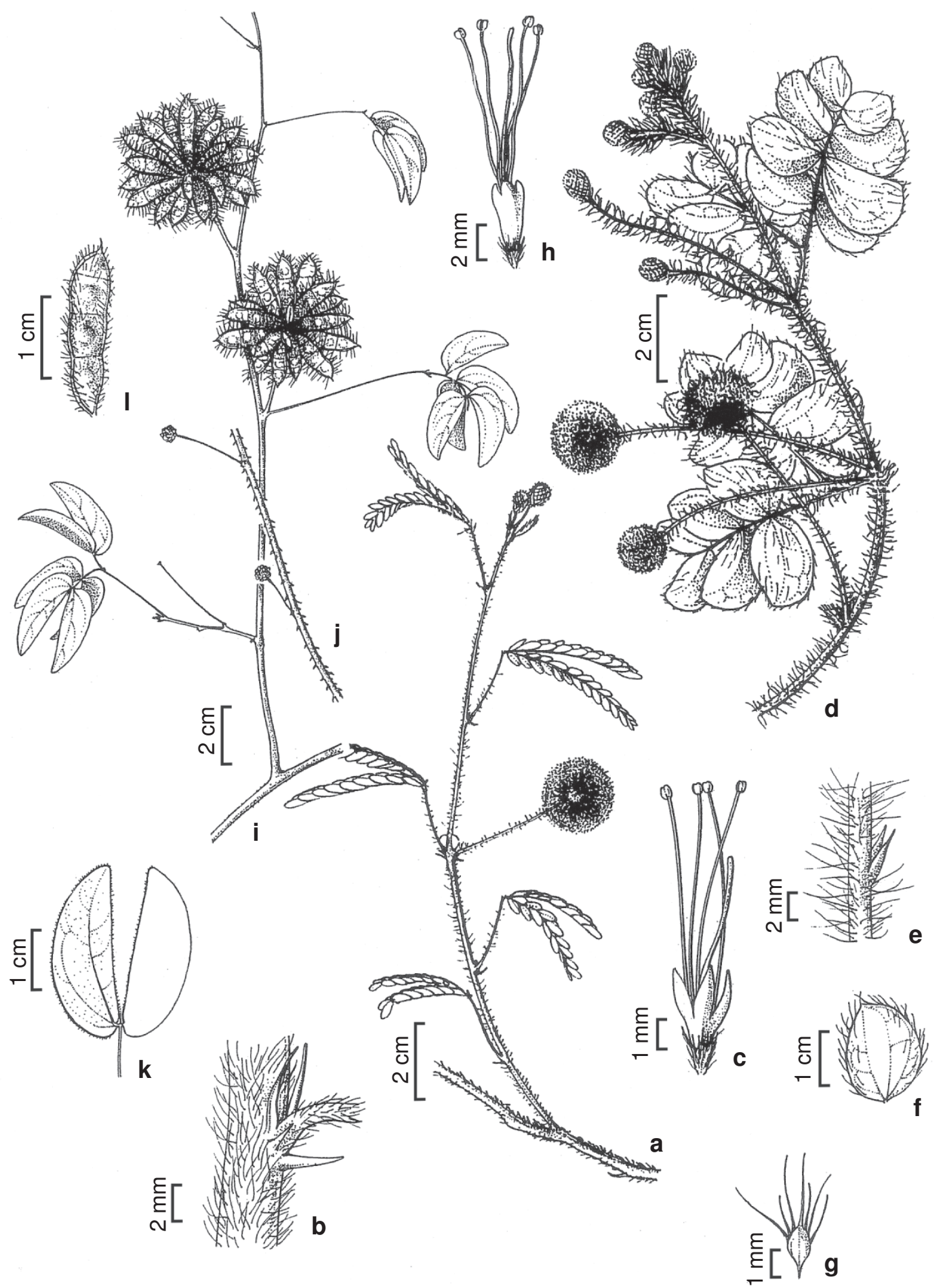

Figura 4-a-c. Mimosa hirsutissima var. hirsutissima - a. aspecto geral do ramo; b. detalhe de acúleo infra-peciolar; c. flor (Silva 72). d-h. M. modesta var. ursinoides - d. aspecto do ramo; e. detalhe das estípulas; f. foliólulo; g. bráctea; h. flor (Silva 74). i-1. M. sensitiva var. sensitiva - i. aspecto geral do ramo; j. detalhe dos acúleos; k. foliólulos; 1. fruto (Silva 80). 
oblanceolada, ciliada. Botões 1,7-2 mm compr. Flores isostêmones, tetrâmeras, sésseis, glabras; cálice $0,2-0,3 \mathrm{~mm}$ compr., papiforme; corola 1,5-2 $\times 0,5 \mathrm{~mm}$, campanulada, creme com a porção apical rósea, lobos 4, elípticos; estames 4, livres; filete 5-8 mm compr., lilás; antera obovóide; ovário $0,8-0,9$ mm compr., estipitado, glabro; óvulos 4; estilete 5-9 mm compr. Craspédio 1,53,0 $\times 1,3-1,4 \mathrm{~cm}$, estipitado, cartáceo, oblongo, superfície ondulada armada com espinhos cônicos, base atenuada, ápice redondo, puberulentoescabroso, marrom-escuro; replo levemente constrito entre os segmentos seminais, puberulentoescabroso. Sementes 2-4, ovóides, marrons.

Material examinado: BRASIL. PERNAMBUCO: Buíque, estrada Buíque-Catimbau, 17.I.1995, fl, $L$. Figueiredo et al. 98 (PEUFR); 26.VII.2005, fl., J. S. Silva et al. 74 (PEUFR); fazenda Pitití, 1.XI.1961, fl. e fr., D. A. Lima 61-3975 (IPA); fazenda Baixa Preta, 10.IV.1955, fl., D. A. Lima 52-2032 (IPA).

Mimosa modesta var. ursinoides pode ser reconhecida pelos foliólulos obovais, nervação actinódroma, craspédio equinado com espinhos cônicos e pelas brácteas oblanceoladas. Barneby (1991) reconheceu para esta espécie duas variedades: M. modesta var. modesta Mart. e M. modesta var. ursinoides diferenciadas, principalmente, pelo indumento. $\mathrm{Na}$ área de estudo só foi registrada $M$. modesta var. ursinoides, que está distribuída apenas na Região Nordeste do Brasil (BA, PE, PI), em vegetação de caatinga (Barneby 1991). No Vale do Ipanema, ocorre em vegetação de caatinga em solos arenosos. Foi coletada com flores nos meses de junho e julho e com fruto em novembro.

3.3. Mimosa sensitiva $\mathrm{L}$. var. sensitiva $\mathrm{Sp}$. Pl. 1: 518 .1753.

Fig. 4 i-1

Subarbusto 1,6-2 m alt., decumbente. Ramos cilíndricos, aculeados, puberulentos; acúleos retrorsos densamente distribuídos nos ramos, pecíolo e pedúnculo; estípulas 3-5 mm compr., estriadas, lanceoladas, ciliadas. Folhas 2 pinas; pecíolo 3,4-5,9 $\mathrm{cm}$ compr., anguloso, puberulento; pinas 1,5-4 cm compr., 4 folioluladas, foliólulos os mais internos atrofiados, membranáceos, oval-lanceolados, base truncada, ápice arredondado a mucronado, margem ciliada, face adaxial glabra, abaxial puberulenta-estrigosa; nervação broquidódroma. Inflorescências glomeruliformes, solitárias, axilares; pedúnculo 3$3,5 \mathrm{~cm}$ compr., pubescente; brácteas 4-4,3 mm compr., triangulares, ciliadas. Botões 1,1-1,8 mm compr. Flores isostêmones, tetrâmeras, sésseis; cálice 1,1-1,2 mm compr., papiforme, glabro; corola 2,7-3×0,4-0,8 mm, campanulada, creme, externamente puberulenta, tricomas adensados no ápice, internamente glabra, lobos 4, elípticos; estames 4, livres; filete 0,4-0,9 mm compr., rosado; antera oblongo-globosa; ovário 0,4-0,9 mm compr., séssil, glabro; óvulos 3-4; estilete 0,7-0,9 mm compr. Craspédio 1,5-2,3 × 0,5$0,7 \mathrm{~cm}$, séssil, coriáceo, elíptico, superfície discretamente ondulada, base arredondada, ápice caudado, hirsuto, amarelado; replo reto, hirsuto. Sementes 3-4, ovóides, acinzentadas.

Material examinado: BRASIL. PERNAMBUCO: Buíque, estrada para Catimbau, 10.IX.1995, fr., $K$. Andrade et al. 239 (PEUFR); 24.II.1996, fr., K. Andrade et al. 336 (PEUFR); serra de Catimbau, 10.I.1996, fr., K. Andrade et al. 300 (PEUFR); 27.VII.2005, fl., J. S. Silva et al. 80 (PEUFR).

Mimosa sensitiva é uma espécie bem delimitada. Caracteriza-se pelos acúleos retrorsos, uniformemente distribuídos pelos ramos e pecíolo, foliólulos oval-lanceolados (quatro por pina), sendo os mais internos atrofiados, nervação broquidódroma, craspédio coriáceo e hirsuto e sementes acinzentadas (marrons nas demais espécies). É muito próxima de $M$. velloziana Mart., com a qual tem sido constantemente confundida, embora difira, principalmente, pelo cálice papiforme. Barneby (1991) reconhece para essa espécie duas variedades: $M$. sensitiva var. malitiosa (Mart.) Barneby e M. sensitiva var. sensitiva, diferenciadas pelo tamanho das brácteas e das inflorescências. Apresenta distribuição exclusiva na América do Sul, sendo encontrada na Venezuela e no Brasil (Amazônia, Bahia e Minas Gerais) (Barneby 1991). Na área de estudo foi encontrada em vegetação arbustiva perenifólia crescendo em solo arenoso. Floresce em abril e frutifica em janeiro, fevereiro e outubro. 


\section{Conclusões}

Os caracteres morfológicos mais relevantes para o reconhecimento das espécies de Mimosa ocorrentes no Vale do Ipanema são observados no tipo de indumento e de inflorescência, no número de pinas, foliólulos, de elementos do perianto e de estames, além do aspecto do fruto. A maior parte das espécies apresenta distribuição em vegetação de caatinga, apenas M. hirsutissima var. hirsutissima, M. gemmulata var. adamantina, M. misera e $M$. sensitiva var. sensitiva ocorrem em vegetação arbustiva perenifólia.

\section{Agradecimentos}

A Fundação de Amparo a Ciência e Tecnologia do Estado de Pernambuco (FACEPE) pela bolsa concedida e à Fundação $\mathrm{O}$ Boticário de Proteção à Natureza pelo financiamento do projeto. Aos curadores dos herbários PEUFR, UFP, HST e IPA, pelo livre acesso as suas instalações e empréstimo de exsicatas.

\section{REFERÊNCIAS BibLIOGRÁFICAS}

Barneby, C. R. 1985. The genus Mimosa (Mimosoideae) in Bahia, Brazil: new taxa and nomenclatural adjustments. Brittonia 37: 125-153.

1991. Sensitivae Censitae. A description of the genus Mimosa L. (Mimosaceae) in the New World. New York Botanical Garden 65: 1-835.

Bell, A. C. 1991. Plant form: an illustrated guide to flowering plant morphology. Oxford University Press, Oxford, 315p.

Bentham, G. 1841. Notes on Mimoseae, with a short synopsis of species. Journal of Botany 4: 243-392.

1875. Revision of the suborder Mimoseae. Transactions of the Linnean Society London 30: 335-664.
1876. Leguminosae - Mimosoideae. In: von Martius, C. E. P.; Eichler, A. W. \& Urban, I. Flora brasiliensis. Munchen, Wein, Leipzig 15(2): 456-458.

Burkart, A. 1948. Las especies de Mimosa de la flora Argentina. Darwiniana. 8: 9-231.

Ducke, A. 1953. As leguminosas de Pernambuco e Paraíba. Memórias do Instituto Oswaldo Cruz 51: 417-461.

Hickey, L. J. 1973. Classification of the architecture of dicitiledonous leaves. American Journal of Botany. 60: 17-33.

Lewis, G. P. 1987. Legumes of Bahia. Royal Botanic Gardens, Kew, 369p. 1995. Leguminosae In: Flora of the Pico das Almas Chapada DiamantinaBahia, Brazil. Royal Botanic Gardens, Kew. Pp. 368-394.

2006. Leguminosae subfamília Mimosoideae. In: Barbosa, M. R. V.; Sothers, C.; Mayo, S.; Gamarra-Rojas, C. F. L. \& Mesquita, A. C. Checklist das plantas do Nordeste brasileiro: angiospermas e gymnospermas. Ministério da Ciência e Tecnologia, Brasília. Pp. 86-90.

Linnaeus, C. 1753. Mimosa. In: Species plantarum. Impensis Laurentii Salvii. Pp. 516-523.

Lins, D. M. T. 1984. Mimosa (LeguminosaeMimosoideae) Série Lepidotae no Rio Grande do Sul. Dissertação de Mestrado. Universidade Federal do Rio Grande do Sul.

Radford, A. E.; Dickson, W.C.; Massey, J. R. \& Bell, C. R. 1974. Vascular plant systematics. Harper \& Row, New York, 891p.

Simon, M. F. \& Proença, C. 2000. Phytogeographic patterns of Mimosa (Mimosoideae, Leguminosae) in the Cerrado biome of Brazil: an indicator genus of high-altitude centers of endemism? Biological Conservation 96: 279-296. 